\title{
Implementation of improvement actions in a company that produces frames and moldings
}

\section{Implementación de acciones de mejora en una empresa que produce marcos y molduras}

\author{
FORNÉS-RIVERA, René Daniel†*, CONANT-PABLOS - Marco Antonio, CANO-CARRASCO \\ Adolfo and LÓPEZ-ROJO, Gildardo Guadalupe
}

Instituto Tecnológico de Sonora, Departamento de Ingeniería Industrial, Campus Ciudad Obregón, Sonora.

ID $1^{\text {st }}$ Author: René Daniel, Fornés-Rivera / ORC ID: 0000-0002-7438-0056, Researcher ID Thomson: G-3906-2018, arXiv Author ID: rene_fornes, CVU CONACYT ID: 280435

ID $1^{\text {st }}$ Co-author: Marco Antonio, Conant-Pablos / ORC ID: 0000-0002-3364-3702, Researcher ID Thomson: G-39112018, arXiv Author ID: Mconant, CVU CONACYT ID: 687331

ID $2^{\text {nd }}$ Co-author: Adolfo, Cano-Carrasco / ORC ID: 0000-0002-3392-3667, Researcher ID Thomson: G-5035-2018, arXiv Author ID: adolfo. cano, CVU CONACYT ID: 276064

ID $3^{\text {rd }}$ Co-author: Gildardo Guadalupe, López-Rojo / ORC ID: 0000-0001-7740-6613, Researcher ID Thomson: Gildardo Lopez, arXiv Author ID: Gildardo_Lopez

DOI: $10.35429 / J R D \cdot 2021.19 .7 .22 .30$

Received March 26, 2021; Accepted June 24, 2021

\begin{abstract}
This research was developed in a company that manufactures frames and moldings in the production and quality area and addresses the need to implement improvement actions due to rework and low production in the patching workstation, derived from flaws such as poor patching, bump, bubble and porosity in the products. Currently there is a production record of $1.75 \%$ and rework of $19.25 \%$ in the first hours of the working day. The objective was to implement improvement actions, through the 8D's methodology, to reduce rework and increase production. The procedure implied forming a team; defining the problem; implementing containment actions; identifying and verifying the root cause; determining permanent corrective actions; identifying and implementing permanent corrective actions; preventing the recurrence of the problem and/or root cause, and acknowledging the effort of the team. It contributed with the increase in production and reduction of rework in the patching workstation, thus fulfilling the objective of this research.
\end{abstract}

Improvement actions, Implementation, 8D's

\begin{abstract}
Resumen
Esta investigación se desarrolló en una empresa elaboradora de marcos y molduras en el área de producción y calidad y aborda la necesidad de implementar acciones de mejora a consecuencia de retrabajos y baja producción en la subárea de resane, derivada de defectos tales como: mal resane, golpes, burbuja y porosidad en los productos. Actualmente se tiene un registro de producción de un $1.75 \%$ y de retrabajo de un $19.25 \%$ en las primeras horas de la jornada laboral. El objetivo consistió en implementar acciones de mejora, a través de la metodología 8D's, para reducir el retrabajo e incrementar la producción. El procedimiento fue: Formar un equipo; definir el problema; implementar acciones de contención; identificar y verificar la causa raíz; determinar acciones correctivas permanentes; identificar e implementar las acciones correctivas permanentes; prevenir la recurrencia del problema y/o causa raíz y reconocer el esfuerzo del equipo. Se contribuyó con el incremento en la producción y reducción de retrabajos en la subárea de resane, Cumpliendo así con el objetivo de esta investigación.
\end{abstract}

Acciones de mejora, Implementación, 8D`s

Citation: FORNÉS-RIVERA, René Daniel, CONANT-PABLOS - Marco Antonio, CANO-CARRASCO Adolfo and LÓPEZ-ROJO, Gildardo Guadalupe. Implementation of improvement actions in a company that produces frames and moldings. Journal of Research and Development. 2021. 7-19: 22-30

\footnotetext{
* Correspondence to Author (e-mail: rene.fornes@itson.edu.mx)

$\dagger$ Researcher contributing as first author.
} 


\section{Introduction}

Industrialization is an economic phenomenon based on the intensive production of goods. This development, in turn implies the creation of workers increasingly prepared to tackle new tasks, as well as the adaptation of production processes to the new tasks that have appeared, preserving and increasing their productivity. (Sánchez, 2021). Productivity is the relationship between final production and productive factors used to obtain goods and services; and this should be measured as a ratio of the output divided by the input, Carro and González (2021); while for Gutiérrez and Huaman (2014), López (2018) and Vásquez (2018) productivity serves to evaluate the performance of workshops, machinery, work teams and employees.

On the other hand, for Evans and Lindsay (2020), a process is a sequence of linked activities whose objective is to achieve some result, such as producing a good or service for a client inside or outside the organization; in turn, for Louffat (2017) it is the set of sequential and integrated activities that aim to generate value for an internal or external client, through the transformation of inputs into final products or services. For Martin and Rodríguez (2019) and Torres (2019), corrective and preventive actions must be supported by the prior evaluation of the situation, so it cannot be immediate; these actions represent a proposal for improvement that arises as a consequence of having studied the cause of a non-conformity detected in the company when applying corrective and preventive actions.

For ISOTools (2016), some organizations have effective systems, each of which may have its own improvement system. Consequently, quality is achieved, which is perfection in relation to the execution of productive activities, where it is guaranteed that the product is well-made, produced on time, preserving the environment and considering worker safety (Morales and Muñoz, 2019). The organization shall consider the results of the analysis and evaluation, and the outputs of the management review, to determine if there are needs or opportunities that should be considered as part of continuous improvement (ISO 9001: 2015, 2018).
Continuous improvement is associated with a diversity of organizational developments, including the adoption of modern approaches such as Total Quality Management (TQM), Lean Manufacturing, Theory of Constraints (TOC), Six Sigma (SS), Kaizen, among others (Singh \& Singh, 2015). Continuous improvement has an advantage since the standard collects valuable information and optimized processes to be able to implement continuous improvement methodologies that make synergy with the quality management system and thus be able to have better monitored processes achieving a better quality of products and services that exceed expectations and customer needs (Pava et al, 2019).

In the same way, it can be considered as a process of change, development and possibilities of improvement by applying this criterion to people and organizations, having as its origin the word Kaizen that implies continuous improvement day by day and at all times; in turn, Deming's circle seeks to raise the quality and performance level of organizations so that they are competitive, in the midst of an environment subject to constant changes; Similarly, there is a structured methodology to obtain, prioritize and evaluate Kepner-Tregoe information, also called the competitive profile matrix; there is also the Six Sigma methodology which is a set of techniques and tools for improving business processes and results; finally, the 8D's methodology (Eight Disciplines Problem Solving) which is based on the basic idea of identifying and correcting the root cause of the problem and taking actions to avoid the recurrence of the failure, devise a short-term solution and implement a long-term solution to avoids its recurrence (Bernal-Moreno, 2014).

The first to have a standard of the 8 disciplines was the United States in the period of the Second World War MIL-STD-1520, known as corrective action and disposition of nonconforming material; presented in 1974, it was used as a method to deal with non-conformities. The main objective of the method was to identify the error, examine the root cause of the problem, limit losses, prevent recurrences and reduce production costs by promoting an increase in quality (Mello de Lima, 2017 and Bosch Inc. 2013). Nowadays, it has become a standard in other organizations that are not in the automotive sector and that adopt this problem-solving methodology (SPC Group, 2020). 
The methodology consists of 8 actions; namely, D1: Set a team; D2: Define the problem; D3; Implement containment actions; D4: Identify and verify the root cause; D5: Determine permanent corrective actions; D6: Implement and verify permanent corrective actions; D7: Prevent the recurrence of the problem and/or its root cause; and D8: Acknowledge the efforts of the team (Mello de Lima, 2017 and Bosch Inc. 2013).

For Soto (2018) the quantification or numerical translation of the dimensions is an indicator, which must be represented clearly and precisely. According to López and Valdiviezo (2017), the indicators allow us to optimally evaluate the operation of the management system and plan activities according to the goals and objectives set by the department. The costs are implicitly stated; which for MuyulemaAllaica et al. (2020) are the unavoidable expenses to maintain a production line; and in relation to the latter; Torres (2017) maintains that the decrease in the budget limits the amount of investments programmed to keep the company at its optimal level; affecting its productivity.

The company under study is dedicated to the manufacture of mirrors, giclees, oils, lithography and sandblasting for decoration, it has a staff of 80 people between general and administrative operators. The market it serves is national and international; it includes department stores, large commercial chains, hotels, furniture stores, decoration stores and finally specific clients or exclusive projects. The production process begins with the reception of the raw material and continues with carpentry, molding, inspection, casting, patching, finishing, assembly, packaging, shipment and end customer (Alfa-Delta, S.A. de C.V., 2019).

In the months of January-May 2019, the company documented the processes and procedures that are carried out to have a better control over them; thus, the managers obtained real data from the areas of interest such as production and quality, deciding to attend the patching, finishing, and assembly workstations; given that it is urgent for the company to be aware of the performance, since a large number of products from the finishing and assembly workstations are sent back to the patching workstation and the reason is unknown.
This affects daily production, with the bottleneck being located in the patching workstation and the reason for this project is because this is the area that determines the production rate. In September, the processes in the different workstations were diagnosed and analyzed in order to take a sample and learn about the current situation of the company and thus be able to determine the problems to be solved along with the managers. Table 1 displays the product behavior.

\begin{tabular}{|c|c|c|}
\hline Schedule & $\begin{array}{l}\text { Produced } \\
\text { amount }\end{array}$ & $\begin{array}{c}\% \\
\text { Production }\end{array}$ \\
\hline $8-9 \mathrm{am}$ & 5 & $1.75 \%$ \\
\hline 9-10 am & 21 & $7.34 \%$ \\
\hline $10-11 \mathrm{am}$ & 30 & $10.49 \%$ \\
\hline $11-12 \mathrm{pm}$ & 38 & $13.29 \%$ \\
\hline $12-1 \mathrm{pm}$ & 34 & $11.89 \%$ \\
\hline $2-3 \mathrm{pm}$ & 34 & $11.89 \%$ \\
\hline $3-4 \mathrm{pm}$ & 37 & $12.94 \%$ \\
\hline $4-5 \mathrm{pm}$ & 42 & $14.69 \%$ \\
\hline $5-6 \mathrm{pm}$ & 45 & $15.73 \%$ \\
\hline & 286 & $100.00 \%$ \\
\hline
\end{tabular}

Table 1 Production sampling of the patching area Source: Alfa-Delta, S.A. de C.V. (2019)

As we can see, there is a low level of production at the beginning of the working day; similarly, the analysis of the flaws was carried out, see Table 2 .

\begin{tabular}{|l|r|}
\hline \multicolumn{1}{|c|}{ Flaw } & Percentage of flaws \\
\hline Poor patching (18/48) & $37.50 \%$ \\
\hline Bump (25/48) & $52.08 \%$ \\
\hline Bubble (3/48) & $6.25 \%$ \\
\hline $\begin{array}{l}\text { Porosity } \\
\text { 48 defective pieces }\end{array}$ & $4.16 \%$ \\
\hline
\end{tabular}

Table 2 Percentage of flaws in patching Source: Alfa-Delta, S.A. de C.V. (2019)

Once the percentage of flaws was obtained, we proceeded to obtain the percentage of rework, which consists of reducing/eliminating the errors derived from production, generating flaws such as poor patching, bumps, bubbles and porosity in aspects such as: bad sanding, bad patches in mahogany, a poor putty application, a poor patching with a filler, and an inadequate bubble extraction; see Table 3 .

\begin{tabular}{|l|r|}
\hline Total of pieces produced & 286 \\
\cline { 2 - 2 } Total of pieces with flaws & 48 \\
\hline Percentage of rework & $16.78 \%$ \\
\hline
\end{tabular}

Table 3 Percentage of rework in patching Source: Alfa-Delta, S.A. de C.V. (2019) 
Because the sampling carried out was only diagnostic, the company requires a longer analysis to determine what the causes of these problems are, especially in the first hours of the working day in the patching workstation, aiming to implement improvement actions through the information obtained and analyzed, to reduce rework and increase production in the first hours of the working day in the patching workstation in the company under study.

\section{Methodology to be developed}

The object of study was the production process in the patching workstation in a company located in the industrial zone of Ciudad Obregón, Son. The materials were the process documentation of Morales and Muñoz (2019) and the methodology of the 8D's of Mello de Lima (2017) and Bosch Inc. (2013). The procedure was: D1) selection of the project team; D2) definition of the problem; D3) implementation of containment actions; D4) identification and verification of the root cause; D5) determination of permanent corrective actions; D6) identification and implementation of permanent corrective actions; D7) prevention of recurrence of the problem and/or root cause; and D8) acknowledgement of the team effort.

\section{Results}

The result obtained is presented and it contains tables, which due to their size, only a part will be presented.

\section{D1) Formation of the project team}

The work team was formed, made up of the director of operations, production, quality and two collaborators.

\section{D2) Definition of the problem}

Once established, the collaborators analyzed the information that was generated in two weeks in which four types of flaws occurred on inspection table one, see Table 4.

\begin{tabular}{|l|r|}
\hline \multicolumn{1}{|c|}{ Flaw } & Flaw percentage \\
\hline Poor patching & $41.40 \%$ \\
\hline Bump & $37.29 \%$ \\
\hline Bubble & $18.60 \%$ \\
\hline Porosity & $2.72 \%$ \\
\hline
\end{tabular}

Table 4 Percentage of flaws in the patching workstation
With the results obtained and with the production of the two weeks analyzed, the rework percentage was obtained, see Table 5.

\begin{tabular}{|l|r|}
\hline Total of pieces produced & 639 \\
\cline { 2 - 2 } Total of pieces with flaws & 123 \\
\hline Percentage of rework & $19.25 \%$ \\
\hline
\end{tabular}

Table 5 Percentage of rework for patching

Maintaining a low production index, see Table 1, in the first hours of the working day of $1.75 \%$.

\section{D3) Implementation of containment actions}

Once having the necessary information, two containment actions were implemented, due to the variability of production per operator, this caused by the organization in the product flow. This is where the first inputs first outputs were implemented, as can be seen in Figure 1.

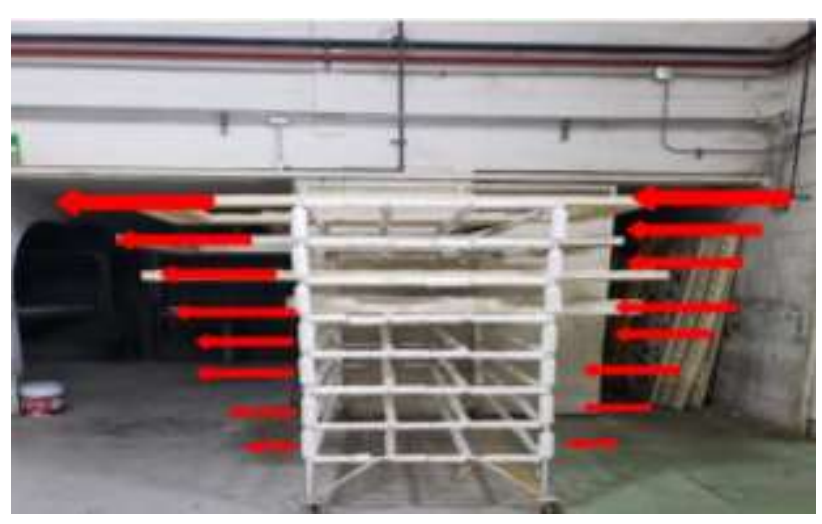

Figure 1 First inputs first outputs Source: Alfa-Delta, S.A. de C.V. (2019)

Continuing with the second containment action, the operator was changed due to his advanced age and lack of motivation in the activity carried out, resulting in the failure to identify defective parts in two consecutive weeks, being unacceptable because the activities performed by the operators involve manual work.

\section{D4) Identification and verification of the root cause}

The task of collecting information was carried out in October where the variation between what was produced in the patching workstation with a total of 1496 frames and what was produced in the assembly workstation with a total of 1321 frames is verified, which generates a gap of less than 175 frames, unknowing its location. The flaws can be seen in Table 6 .

FORNÉS-RIVERA, René Daniel, CONANT-PABLOS - Marco Antonio, CANO-CARRASCO Adolfo and LÓPEZ-ROJO, Gildardo Guadalupe. Implementation of improvement actions in a company that produces frames and moldings. Journal of Research and Development. 2021 


\begin{tabular}{|l|r|}
\hline \multicolumn{1}{|c|}{ Flaw } & Percentage of flaws \\
\hline Poor patching & $30.80 \%$ \\
\hline Bump & $39.16 \%$ \\
\hline Bubble & $24.71 \%$ \\
\hline Porosity & $5.32 \%$ \\
\hline
\end{tabular}

Table 6 Flaws from October for patching

Once having identified the problems, we undertook the task of investigating what the root cause was, for this the $5 \mathrm{~W}+\mathrm{H}$ technique was developed in which the possible causes of the different problems were discovered starting with the bump, finding that the cause was the lack of training for the personnel to handle the product, and the lack of protections in the transport equipment, as well as a poor patching, where there was a poor training for the operators; the production problem continued, where low productivity was found at the beginning of the day, as well as a lack of supervision; as well as the implementation of a stock for the beginning of the next day. Finally, the difference between what patching produces and what assembly does was analyzed, finding the non-existent training in the handling of reworked product and that there is no special transport equipment for reworked product being the cause of ignorance of all 175 frames.

\section{D5) Determination of permanent corrective actions}

With the root causes identified, the team met with the following corrective actions:

1) Adaptation of protections to the transport equipment to reduce or eliminate the shock caused by moving the products.

2) Training of operators, to reduce the large number of rework due to damages and defects due to mishandling the product and incorrect patching.

3) Implementation of a transport equipment for rework, to reduce the variation of what is produced in the patching and assembly workstations, due to the loss of produced parts.

4) Implementation of stock at the beginning of the day: to ensure that operators have product when they arrive to their work station.

\section{D6) Implementation and verification of permanent corrective actions}

As an improvement action for the transport equipment, protective tape was applied and fom adapted to the lateral crossbar, see Figure 2.

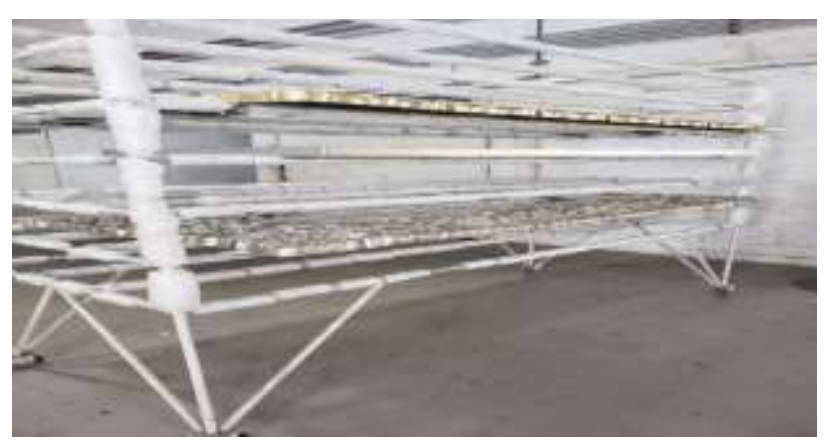

Figure 2 Protection of transport equipment Source: Alfa-Delta, S.A. de C.V. (2019)

Moving on to the next implemented action, which was the training of operators when they did not perform their work correctly, the operations and quality director met and trained the operators of the patching and finishing workstations; reducing the bumps and the poor patching. For the results of this, the percentage of defects within the total defects was considered, before and after the implementation of the corrective actions, see Table 7.

\begin{tabular}{|l|r|}
\hline Flaw & Percentage of flaws \\
\hline Poor patching & $15.84 \%$ \\
\hline Bump & $10.89 \%$ \\
\hline Bubble & $38.61 \%$ \\
\hline Porosity & $34.65 \%$ \\
\hline
\end{tabular}

Table 7 Flaws in the patching workstation

As seen in table 7 , once the corrective actions were implemented, the flaws per bump decreased from $52.08 \%$ to only $10.89 \%$ and the flaws due to poor patching went from $37.5 \%$ to $15.84 \%$, with which the defects due to bubble and porosity became the most significant because they were testing new chemical components which were not tackled by delimitation in the present project, in addition to the fact that these, as known, are produced mainly due to the chemical reactions of the raw material used (polyurethane ) by its very nature and the effect that the environment has over it. Regarding rework, there was $19.25 \%$ in the diagnosis made, with improvements in this area, see Table 8 . 


\begin{tabular}{|l|r|r|r|}
\hline \multicolumn{1}{|c}{ Indicator/Month } & \multicolumn{1}{c}{ Sep. } & \multicolumn{1}{c|}{ Oct. } & Nov. \\
\hline Total of pieces produced & 1292 & 1496 & 1128 \\
\hline $\begin{array}{l}\text { Total of pieces with } \\
\text { flaws }\end{array}$ & 234 & 263 & 101 \\
\hline Percentage of rework & $18.11 \%$ & $17.58 \%$ & $8.95 \%$ \\
\hline
\end{tabular}

Table 8 Evolution of the percentage of rework

The third action was to implement a transport equipment for rework, to eliminate variation between what comes out of the patching workstation and what comes out of the assembly workstation, see Figure 3. With the production analysis, the total and the difference of frames produced in the month of November was identified, see Table 9.

\begin{tabular}{|l|r|r|r|r|}
\multicolumn{1}{l|}{ Patchig Assembly Difference } & $\begin{array}{r}\text { \% Dif. * } \\
\text { Absolute }\end{array}$ \\
\hline Before & 1496 & 1321 & -175 & $13.25 \%$ \\
\hline Now & 1128 & 1177 & +49 & $4.34 \%$ \\
\hline
\end{tabular}

Table 9 Difference between production patchingassembly

* Difference/production of the workstation with the lowest production

As seen in table 8, the implementation of the improvement action made it possible to reduce the difference in production between the areas from $13.25 \%$ to $4.34 \%$; in addition to the fact that due to the production flow, we are able to notice that unlike before, the assembly workstation now shows an overproduction in relation to patching, which may be due to the fact that it is in the process of recovering the missing parts, which were in production, but up to this point we had not had knowledge of them.

Finally, due to the low productivity at the beginning of the day, the stock was implemented (Being a simple way to calculate it; divide the desired daily production by the working day $(9$ hrs) establishing the stock as the difference between the desired production average per hour, minus the average production during the first hour of the work day, example: Considering the production of the month of October of 1436 frames.

\footnotetext{
$-\quad$ Production first hour $=1436(0.0175)=$ 25 frames

- $\quad$ Desired production $/ \mathrm{hr} .=1436 / 9=160$ frames

- $\quad$ Stock $=160-25=135$ frames) of material to improve operator performance. Figure 3 shows the implemented improvement.
}

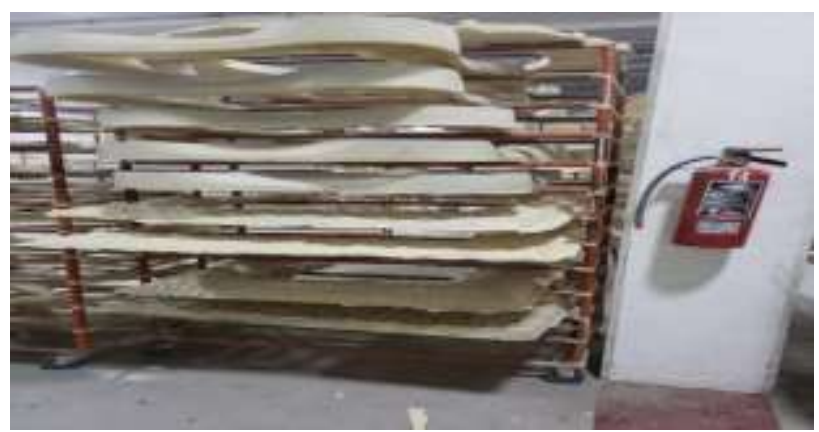

Figure 3 Stock for the beginning of the day Source: Alfa-Delta, S.A. de C.V. (2019)

After the implementation of the stock for the beginning of the day, an increase in production is appreciated, see Graph 1 .

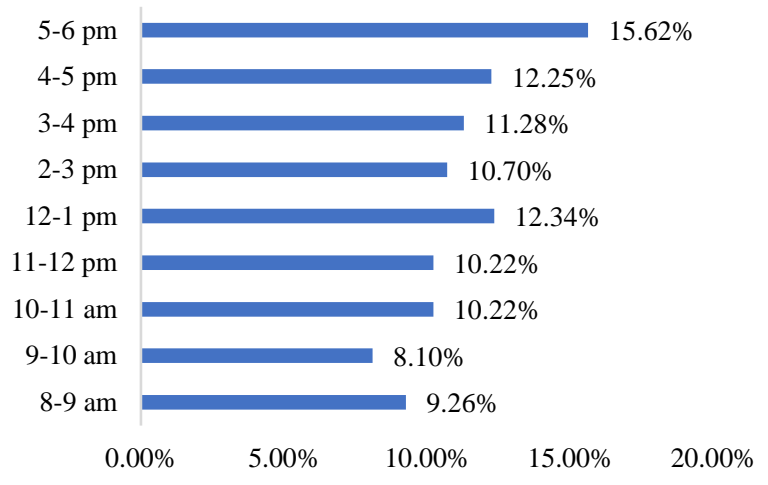

Graph 1 Production percentage of patching in November Source: Alfa-Delta, S.A. de C.V. (2019)

Another way to see the improvement or increase in production with the implementation of the stock is the increase in daily production from 1436 to 1596 frames/day.

\section{D7) Prevention of the recurrence of the problem and/or root cause}

To avoid recurrences of the problems that were tackled by the improvements, a series of actions is shown:

a) Maintenance plan for the transport equipment. To prevent the recurrence of damage and alterations in the final product during its journey through the different areas of the production line, it is recommended to change the protective tape every three months or when it appears damaged due to wear, since this is the life-span estimated for it; on the other hand, the change of the protective fom will be carried out annually. 
b) Stock of raw materials to start daily work. To ensure the supply of raw material, it is observed that the initial raw material stock must be calculated (as was done previously) and the raw material count must be carried out in the last hour of the working day in this case from 5:00 $\mathrm{pm}$ to 6:00 pm, by a supervisor and be signed by the director of operations.

c) Staff training. We prepared a table of competencies that shows the capacities that an operator must have in order to carry out their day-to-day work, which include capacities for: a) sanding; b) putty application; c) application of mahogany patch; d) putty filler; and d) bubble extraction, with a weighting; being number one, not competent, number two, moderately competent and number three competent; as they are related to the patching workstation, the finishing workstation also designed a production format that assesses the capacities in the process of: a) grinding; b) scratching; c) classics; d) broaching; e) formulation of inks; and f) knowing how to carry out a final inspection of the product. Similarly, to the assembly area personnel: a) glass cutting; b) oil painting; c) styrene mount; and d) wallpaper.

d) Control over the reworked product. It was designed including the necessary specifications to facilitate the filling of the operator, as well as the understanding of the content for its readers, such as its area of origin (finishing or assembly) as well as the name of the operator who is working on it (this way we can also monitor performance) includes the name of the type of flaw that the product suffered and, finally, after the rework has been carried out, the name of the person who released it.

\section{D8) Acknowledgement of the team effort}

In this section, a comparative analysis was carried out of the changes that the process underwent during the months of work, thus showing the achievement obtained through the improvements proposed and implemented in the patching area:
A. Production increased at the beginning of the day from $1.75 \%$ to $9.76 \%$

B. Parts from rework decreased from $19.25 \%$ to $8.95 \%$

C. The most critical types of flaws addressed were:

a. Bump, down from $52.08 \%$ to $10.89 \%$

b. Poor patching, went from $37.50 \%$ to $15.84 \%$

Giving importance to the achievements obtained and encouraging those involved in the way that the company considers best will be very important for a greater involvement of the staff in the continuous improvement of processes and products.

\section{Conclusion}

The purpose of this project was to implement improvement actions, through the collection and analysis of information in the areas of production and quality focused on reducing rework and increasing production in the first hours of the working day. Therefore, once the project is completed and based on each of the results obtained, it is possible to mention its achievement, complying with the proposed objective. Finally, the methodology of the 8 D'S, turned out to be very practical since it allows the improvement of the product establishing a standardized practice to continue seeking to focus on the origin of each problem by determining the root cause to implement effective improvement actions. Consequently, each of the products obtained from the implemented method seeks a positive impact on the rework and production indicator in the company's patching workstation, thereby also generating a better quality in the final product.

\section{Recommendations}

According to the above, it is recommended to form a team which is in charge of carrying out future improvement actions, as well as carrying out new analysis to identify the causes of defects and thus achieve a continuous improvement process. In addition, it is recommended that the necessary maintenance has to be done to the transport equipment, in order to avoid their wear and tear, as well as continuing to apply training for the prevention of manual defects, either in the patching area or in the finishing, quality and production coordinators are recommended to follow up with their workers to maintain what has been achieved in this project.

FORNÉS-RIVERA, René Daniel, CONANT-PABLOS - Marco Antonio, CANO-CARRASCO Adolfo and LÓPEZ-ROJO, Gildardo Guadalupe. Implementation of improvement actions in a company that produces frames and moldings. Journal of Research and Development. 2021 


\section{References}

Alfa-Delta S.A. de C.V. (2019). Informe general de la empresa.

Bernal-Moreno, J.E. (2014). Importancia de la administración y solución de problemas en el desarrollo de productos. [Tesina. Universidad Autónoma del Estado de México]. http://ri.uaemex.mx/bitstream/handle/20.500.11 799/32531/419689.pdf?sequence=2\&isAllowed $=\mathrm{y}$

Bosch, Inc. (2013). Quality Management in the Bosch Group. PROBLEM SOLVING. https://assets.bosch.com/media/global/bosch_gr oup/purchasing_and_logistics/information_for_ business_partners/downloads/quality_docs/gene ral_regulations/bosch_publications/bookletno16-problem-solving_EN.pdf

Carro, R. y González, D. (2021). Productividad y competitividad. Universidad Nacional del Mar de

Plata

http://nulan.mdp.edu.ar/1607/1/02_productivida d_competitividad.pdf

Evans, J. y Lindsay, W. (2020). Administración $y$ control de la calidad 10a Ed. CENGAGE. https://itson.vitalsource.com/\#/books/97860752 69276/cfi/4!/4/4@0:0.00Gutiérrez, H. y Huaman, A. (2014). Influencia de la motivación laboral en la productividad en la financiera uno Oechsle - Huancayo. (Tesis de pregrado). Universidad Nacional Del Centro Del Perú, Huancayo, Perú. http://repositorio.uncp.edu.pe/bitstream/andle/U NCP/2474/Gutierrez\%20HuamanHuaman\%20 Araujo.pdf? sequence $=1 \&$ isAllowed $=\mathrm{y}$

ISO 9001:2015. (2018). Sistema de Gestión de Calidad, fundamentos principales. Nueva ISO 9001:2015. https://www. nueva-iso i90012015.com/2018/04/sistema-de-gestión-decalidad-principios/

ISOTools. (2016). OSHAS 180001: 7 pasos para realizar las acciones correctivas es un SG-SST. https://www.isotools.cl/ohsas-180017-pasospara-realizar-las-acciones-correctivas-en-un-sgsst/
López, R. y Valdiviezo, C. (2017). Optimización del sistema de gestión de mantenimiento de la maquinaria pesada del Gobierno autónomo descentralizado de la provincia del Cañar, a través de la gestión por procesos. (Proyecto técnico de pregrado). Universidad Politécnica Salesiana Sede Cuenca, Ecuador. https://dspace.ups.edu.ec/bitstream/123456789/ 14308/1/UPS-CT007027.pdf

López, Z. O. (2018). Cultura organizacional y productividad. Estudio de caso en una microempresa productora de botanas (Tesis de pregrado). Facultad de Contaduría y Administración, Metepec, México. http://ri.uaemex.mx/handle/20.500.11799/9519 3

Louffat, E. (2017). Diseño organizacional basado en procesos. CENGAGE Learning Editores.

https://itson.vitalsource.com/\#/books/97860752 63045/cfi/4!/4/2@100:0.00

Martin, M. y Rodriguez, J. (2019). CAPA Acciones correctivas y preventivas en las industrias alimentarias. Díaz de Santos. https://www.editdiazdesantos.com/wwwdat/pdf 19788490522158.pdf

Mello de Lima, T. (27 de octubre de 2017). nucleo do conhecimento. https://www.nucleodoconhecimento.com.br/ing enieria-de-produccion/metodologia-8d-2

Morales, K. y Muñoz, F. (2019). Actualización de la documentación de procesos con base en la ISO 9001:2015, en una empresa elaboradora de marcos y molduras. [Tesis no publicada] Instituto Tecnológico de Sonora. Ciudad Obregón, Sonora.

Muyulema-Allaica, C. A., Muyulema-Allaica, J. C., Pucha-Medina, P. M., y Ocaña-Parra, S. V. (2020, 01, 04). Los costos de producción y su incidencia en la rentabilidad de una empresa avícola integrada del Ecuador: caso de estudio. Visionario Digital. http://www.cienciadigital.org/revistacienciadigi tal2/index.php/VisionarioDigital/article/view/10 $89 / 2615$ 
Pava, C. Ramírez, J. y Marín, W. (2019). Metodologías de mejora continua integrables al sistema de gestión de calidad bajo la norma ISO 9001. Herramientas y metodologías de mejora continua aplicada al sistema de gestión de calidad bajo la norma ISO 9001. https://repository.usc.edu.co/bitstream/h ¿ndle/20.500.12421/1311/METODOLOG\%C3 $\% 8 D A S \% 20 D E \% 20 M E J O R A . p d f ?$ sequence $=1 \&$ is Allowed $=\mathrm{y}$

Sánchez, J. (2021). Industrialización. https://economipedia.com/definiciones/industria lizacion.html

Singh, J., \& Singh, H. (2015). Continuous improvement pholosophy - literature review and directions. An International Journal. https://doi.org/10.1108/BIJ-06-2012-0038Soto, S. E. (2018). Variables, dimensiones $e$ indicadores en una tesis. https://tesisciencia.com/2018/08/20/tesisvariables-dimensiones-indicadores/

SPC Group. (2020). 8 Disciplinas para la solución de problemas. https://spcgroup.com.mx/8_disciplinas_20_12_ $19 /$

Torres, I. (2019). Corrective actions. https://iveconsultores.com/acciones-correctivas/

Torres, R. (2017). Proposal for the implementation of a preventive maintenance program to reduce maintenance costs, applied in the pulp plant company Trupal S.A. (Tesis de pregrado). Universidad privada del Norte, Trujillo, Perú. de https://repositorio.upn.edu.pe/bitstream/handle/ 11537/13603/Torres\%20Rojas\%20Jaime\%20Pa ul.pdf? sequence $=1 \&$ isAllowed $=y$

Vásquez, P. (2018). Estudio realizado con agentes de la PMT de la municipalidad de San Pedro Sacatepéquez, San Marcos (Tesis de pregrado). Universidad Rafael Landívar, Quetzaltenango, Guatemala. http://recursosbiblio.url.edu.gt/tesiseortiz/2018/ 05/43/Vasquez-Mayra.pdf 